\title{
$=\mathrm{T} R A M A=$
}

\section{VOZES DAS MULHERES INDÍGENAS EM ELIANE POTIGUARA E EM GRAÇA GRAÚNA}

\author{
LUNARA ABADIA GONÇALVES CALIXTO (UFU) ${ }^{1}$
}

\begin{abstract}
RESUMO: Escritores indígenas brasileiros têm atuado com maior intensidade a partir do final do século XX, como uma forma de resistência e de autoafirmação perante a sociedade a qual causou mais de 500 anos de supressão e de apagamento de suas culturas e etnias. Diante dessa proposta, escritoras como Eliane Potiguara e Graça Graúna têm trazido à tona a voz da mulher indígena, a principal atingida pelo processo de espoliação indígena, por meio de textos poéticos que abrangem tanto a luta política por direitos como também uma expressividade lírica. A questão das vozes femininas na poesia dessas duas autoras é de suma importância porque envolve a exaltação de situações que têm sido duplamente apagadas dos processos de representatividade: o gênero feminino e a cultura indígena.
\end{abstract}

PALAVRAS-CHAVE: Literatura de autoria indígena. Vozes das mulheres indígenas. Eliane Potiguara. Graça Graúna.

ABSTRACT: Brazilian indigenous writers have acted with greater intensity since the end of the $20^{\text {th }}$ century as a form of resistance and self-assertion in the face of society which has caused more than 500 years of suppression and erasure of their cultures and ethnicities. Faced with this proposal, writers such as Eliane Potiguara and Graça Graúna have brought to the fore the voice of indigenous women, the main one affected by the process of indigenous plunder, through poetic texts that cover both the political struggle for rights as well as a lyrical expressiveness. The question of female voices in the poetry of these two authors is of paramount importance because it involves the exaltation of situations that have been doubly erased from the representative processes: the feminine gender and the indigenous culture.

KEYWORDS: Literature of indigenous authors. Voices of indigenous women. Eliane Potiguara. Graça Graúna.

\section{INTRODUÇÃO}

A literatura de autoria indígena ainda é uma área pouco difundida no Brasil, seja nos meios de comunicação como também nos meios acadêmicos. Ainda subsiste um preconceito literário no cânone com relação ao texto de origem indígena, sendo deixado à margem dos estudos literários, por ser considerado rudimentar ou de pouco valor estético. Na verdade, a figura do indígena brasileiro dentro da literatura teve como perspectiva principal o olhar do "branco" colonizador e/ou não indígena ao longo do tempo, de modo que visões estereotipadas têm servido como parâmetros de representação.

Essa questão da representação do indígena é muito relevante porque prevaleceu como concepção oficial na cultura brasileira, sendo estereotipada a partir de perspectivas colonizadoras. Exemplos disso são os livros indianistas produzidos na primeira fase do Romantismo no Brasil, no século XIX, tais como O Guarani (1857) e Iracema (1865), de José de Alencar, ou o poema épico O Uraguai (1769), de Basílio da Gama, em que predominava a noção de um índio herói, símbolo nacional, inspirado nos moldes europeus, como os cavaleiros medievais, e em outra direção de sentido, no século XX, o índio considerado como

\footnotetext{
1 Mestra em Estudos Literários pela Universidade Federal de Uberlândia (UFU), e-mail: lunara_calixto@hotmail.com.
} 


\section{$=$ TRAMA $=$}

"preguiçoso", "malandro", conforme a descrição do personagem homônimo na obra Macunaíma (1928), de Mário de Andrade.

Tentando primeiramente desconstruir as concepções preestabelecidas sobre os indígenas no Brasil, surgem os textos de autoria indígena, também chamados de "literatura dos ressurgidos", ou de "literatura de resistência", em que, dentro da perspectiva de Bosi (2002), a escrita se configura como um instrumento de resistência aos processos de silenciamento sofridos. Essa nomeação surge do fato de os povos nativos e seus descendentes começarem a escrever no fim da década de século XX, primeiramente em português, como uma maneira de serem vistos e ouvidos pela sociedade em geral. Tratava-se também de uma forma de desconstrução do passado oficial difundido pela História e demais discursos de poder, ou seja, do lado dos "vencedores", pois conforme Eurídice (2013, p. 149), "Walter Benjamin já havia denunciado o fato de os historiadores positivistas terem empatia pelos vencedores, escrevendo, assim, a história deles e não dos que foram dominados".

Dessa forma, autores de etnia indígena têm buscado o protagonismo na construção identitária a partir da própria voz, não mais mediada pelo outro, colonizador. Em seus textos prevalece um sentido de coletividade, o que representa muito do modus vivendi desses povos. Não há um autor que se propõe a privilegiar a sua voz, mas a voz de todo o seu povo e cultura. Ademais, essa literatura não é direcionada apenas para leitores indígenas, mas principalmente para os que não são, a fim de que esses possam conhecer o outro lado da história, até então silenciado.

De modo geral, o mote principal da literatura de autoria indígena diz respeito a uma autoafirmação e a uma resistência da própria etnia frente ao frequente apagamento por parte da sociedade etnocêntrica. Há uma literatura de afirmação, pois ocorre o anseio de se afirmar como indígena perante o cenário público. Escritores que fazem parte desse movimento, tais como Daniel Munduruku, Olívio Jekupé, Graça Graúna e Eliane Potiguara, também abordam a diáspora e a espoliação sofrida pelos povos aborígenes, além da transculturação vivenciada por eles, que ocasiona um entre-lugar, o qual, dentro da teoria de Santiago (2000), pode ser definido como um trânsito de culturas que interfere em uma tradição original, formando culturas híbridas, as quais podem ser definidas como "uma nova sociedade, a dos mestiços, cuja principal característica é o fato de que a noção de unidade sofre reviravolta, é contaminada em favor de uma mistura complexa entre o elemento europeu e o elemento autóctone" (SANTIAGO, 2000, p. 15). De fato, muitos escritores ameríndios são vistos como estrangeiros dentro do próprio país, pois não pertencem diretamente à aldeia, por não terem nascido e nem sido criado nela, o que ocasiona um distanciamento com os demais indígenas, e nem à cidade, por serem considerados estranhos, exóticos. Diante disso, é tão importante para eles a afirmação de uma identidade. Pode-se dizer que tais escritas estão

no cruzamento de culturas que buscam superar a fratura colonial e se inserem no processo de transculturalidade contemporânea que engendra novas formas de percepção do real e de expressão artística, sem renunciar, no entanto, a expor os sofrimentos do desenraizamento imposto pela colonização (OLIVIERI-GODET, 2017, p. 102).

Portanto, o processo de transculturação, que pode ser definido como transformações mútuas entre culturas que se inter-relacionam, foi um elemento importante para que a voz indígena fosse possível de ser ouvida no mundo ocidental, uma vez que possibilitou uma maior percepção da realidade entre colonizador e colonizado. Entretanto, ao mesmo tempo, é relevante salientar que embora essa literatura se empenhe em reivindicar direitos e denunciar as mazelas dispensadas aos povos originários, não se trata de uma literatura simplesmente 


\section{$=$ TRAMA $=$}

engajada ou panfletária. O texto de autoria indígena apresenta essa característica, de fato, mas também se constitui como um texto trabalhado na linguagem, abrangendo temas como mitos tradicionais, utopias, e até mesmo obras voltadas para o público infantojuvenil. Há tanto poemas quanto narrativas, que partem muitas vezes de histórias contadas oralmente e que foram transmitidas de geração em geração ao longo de muitos anos, séculos, configurando-se como um legado cultural para a humanidade. Nesse sentido, o aspecto literário está presente, o que confirma a sua importância para os estudos literários.

Trazendo autores que se propõem a abordar a representação indígena, principalmente com relação à questão identitária e à subjugação feminina, este artigo elege Eliane Potiguara e Graça Graúna na representação da mulher aborígene, por meio da manifestação de suas vozes. Essas duas autoras não são indígenas aldeadas, ou seja, não vivem diretamente nas aldeias e tribos, mas pertencem ao processo de diáspora, por serem a ascendência de seu povo, o que garante a coerência de seus discursos. Da mesma forma como outros autores indígenas emergentes, a exemplo de Daniel Munduruku, que, sendo graduado em Filosofia, História e Psicologia, além de Doutor em Educação, inaugura o Instituto UKA - Casa dos Saberes Ancestrais como forma de disseminação da cultura indígena e de luta pelos seus direitos, Potiguara e Graúna possuem uma postura política ao revisitarem os discursos oficiais da História com relação à imagem equivocada dos povos aborígenes, buscando tanto reescrever os estereótipos como também a si mesmas, enquanto indígenas. Mesmo assim, elas ainda fazem parte do "entre-lugar" de culturas, o que leva a entender a "ambivalência presente nas obras de autores autóctones urbanos, que parecem oscilar entre uma poética do confronto (que salienta as identificações identitárias) e uma poética da relação (que promove a travessia das fronteiras)" (OLIVIERI-GODET, 2017, p. 102).

A escolha da representação da voz feminina indígena neste artigo deve-se ao fato da pouca importância demonstrada a essa parcela da população, tanto na sociedade etnocêntrica como na literatura: "A ausência ou a pouca representatividade de personagens femininas negras e indígenas não corresponde à realidade social do país, mas é compatível com o fato de os autores publicados [...] serem, na sua maioria, homens brancos" (FIGUEIREDO, 2013, p. 150-151). Esse aspecto demonstra que "não há valor algum atribuído à 'mulher' como item respeitoso nas listas de prioridades globais" (SPIVAK, 2010, p. 126), e com relação à mulher indígena, o apagamento se torna maior.

Na tradição dos povos originários, a figura da mulher é crucial e significativa, porque ela está intimamente relacionada com o sagrado, com a sabedoria, com a ancestralidade e com a fertilidade: "A palavra da mulher é sagrada como a terra" (POTIGUARA, 2004, p. 89). Há os lugares definidos a serem ocupados dentro da aldeia e a mulher detém o seu espaço reconhecido. Desse modo, mulheres nativas aldeadas possuem o seu direito à voz respeitado na sua comunidade, tendo protagonismo na tradição:

O papel da mulher na luta pela identidade é natural, espontâneo e indispensável. A mulher tem a função política de gerar o filho e educá-lo conforme as tradições, assim como na sociedade envolvente. [...] Com relação à cultura indígena, a mulher é uma fonte de energias, é intuição. É a mulher selvagem não no sentido primitivo da palavra, mas selvagem como desprovida de vícios de uma sociedade dominante (POTIGUARA, 2018, p. 44-45).

A autora Eliane Potiguara demonstra a importância de se considerar a indígena como uma mulher primitiva, não no sentido pejorativo de selvagem e inculto, mas no sentido de primeira, forte, que não se deixa subjugar. Essa concepção de "mulher selvagem" coaduna com a proposta de Estés (1999) na obra Mulheres que correm com os lobos, a qual faz várias 


\section{$=$ TRAMA $=$}

considerações sobre a força feminina: "Para encontrar a Mulher Selvagem, é necessário que as Mulheres se voltem para suas vidas instintivas, sua sabedoria mais profunda" (ESTÉS, 1999, p. 20). Para Eliane Potiguara, a mulher primitiva apresenta um papel importante na manutenção da tradição e da identidade de seu povo:

Seu poder é o conhecimento passado através dos séculos e que está reprimido pela história. A mulher, intuitivamente, protege os seios e o ventre contra seu dominador e busca forças nos antepassados e nos espíritos da natureza para a sobrevivência da família. Todos esses aspectos foram mais preservados do que no homem (POTIGUARA, 2018, p. 45).

Isso posto, se a mulher indígena é destruída, toda a cultura a seu redor também se desfaz, pois é a partir dela que se difundem os saberes e as tradições. Essa circunstância reforça o que Estés (1999) disserta sobre a mulher selvagem, fazendo uma analogia entre a mulher e os lobos, e que apresenta uma afinidade com a importância da mulher dentro das comunidades indígenas:

Os lobos saudáveis e as mulheres saudáveis têm certas características psíquicas em comum: percepção aguçada, espírito brincalhão e uma elevada capacidade para a devoção. Os lobos e as mulheres são gregários por natureza, curiosos, dotados de grande resistência e força. São profundamente intuitivos e têm grande preocupação para com seus filhotes, seu parceiro e sua matilha. Tem experiência em se adaptar a circunstâncias em constante mutação. Têm uma determinação feroz e extrema coragem. No entanto, as duas espécies foram perseguidas e acossadas, sendo-lhes falsamente atribuído o fato de serem trapaceiros e vorazes, excessivamente agressivos e de terem menor valor do que seus detratores (ESTÉS, 1999, p. 07).

A partir do momento que essas mulheres saem da aldeia, principalmente por conta da desapropriação de terras, o respeito e a deferência se perdem na sociedade etnocêntrica, e elas passam a se situar no último nível da hierarquia social. Spivak (2010, p. 85) afirma que "se você é pobre, negra e mulher, está envolvida de três maneiras", ou seja, discriminada por três situações, mas considerando a mulher oriunda da cultura indígena, sua voz é mais silenciada ainda, por ser mulher e, ainda, pelo estereótipo de selvagem e de ignorante que permeia a concepção de indígena no Brasil. Dessa forma, as mulheres desaldeadas são espoliadas de toda a sua condição original. A seguir, o relato de Kerexu Yxapyry, ativista e cacica da terra guarani do Morro dos Cavalos, em Palhoça, retirado do site do jornal on-line Catarinas, demonstra esse fato:

Depois do contato (com os colonizadores) nossa mobilidade foi aos poucos sendo restrita por causa das guerras políticas de fronteiras de estados e poder. Nesse período, os colonizadores enxergavam as mulheres apenas como objetos de reprodução. A mulher não tinha voz, somente obedecia ou era punida com muita violência e essas violências vinham de todas as formas (ARAÚJO, 2016).

Exemplo dessas formas de violência é o caso da esterilização imposta a mulheres indígenas, conforme citado por Graúna, uma forma disfarçada de genocídio: "No dia 8 de março de 2001, as organizações indígenas denunciaram o caso de esterilização de mulheres Pataxó Hã-hã-hãe, ocorrido na Bahia, em 1994" (GRAÚNA, 2013, p. 35). A mulher de origem indígena é mais subjugada do que o homem indígena porque, conforme Spivak (2010, p. 66), "apesar de ambos serem objetos da historiografia colonialista e sujeitos da insurgência, a construção ideológica de gênero mantém a dominação masculina". Essa dominação masculina pode ser 


\section{$=$ TRAMA $=$}

traduzida também nas ações do colonizador, que alcança o ápice da destruição indígena quando age diretamente sobre as mulheres, assolando sua etnia e a sua descendência.

Portanto, a atuação de mulheres indígenas na escrita é um grande instrumento de luta contra a dominação sofrida. Eliane Potiguara e Graça Graúna têm se sobressaído na literatura de autoria indígena, principalmente na abordagem de temas feministas e anticolonialistas. Percebe-se nessas autoras uma preferência pela poesia no engajamento que exercem, devido à força expressiva do eu lírico em suas obras, pois, dessa forma, se aproveitam do caráter lírico para representar na escrita os cânticos tradicionais de sua etnia, a musicalidade e a expressividade próprias de sua cultura. Exemplos de importantes livros que apresentam poesia engajada dessas autoras são Metade cara, metade máscara (2018), de Eliane Potiguara, e Canto Mestizo (1999), de Graça Graúna. O ato da escrita configura-se também como lugar de reconstrução identitária e de resiliência, de autoafirmação, apresentando uma dimensão ontológica, na escrita da essência de si e do povo ao qual pertence, além de funcionar como um ato político de resistência.

Com relação à vida dessas autoras, Eliane Potiguara, nascida em 1950 no Rio de Janeiro, é descendente do povo potiguara, oriundo do Rio Grande do Norte. Segundo informações do site oficial de Potiguara², sua avó materna, Maria de Lourdes, era pobre, indígena e analfabeta, e sofreu com a diáspora ainda na infância, perdendo o direito à terra e à sua cultura, após a morte de seu pai, que lutava contra os comandos e desmandos de grupos capitalistas que tentavam desapropriá-los. Sofreu também com abuso sexual, quando, com apenas 12 anos, dá à luz a uma menina, que seria a mãe de Eliane Potiguara. Ainda adolescente, teve que migrar para Rio de Janeiro, a fim de tentar uma vida melhor. A história sofrida de sua avó serviu como inspiração para o seu trabalho engajado na causa indígena. Primeiramente formou-se professora, depois dedicou seu trabalho a ativismos em defesa dos direitos indígenas, sendo atuante até os dias de hoje. Fundou o Grumin (Grupo MulherEducação Indígena), que objetiva a educação e orientação de mulheres indígenas nos seus direitos na sociedade. Os primeiros poemas surgiram a partir de 1975, sendo a primeira mulher indígena brasileira a se destacar na literatura. Seus textos chamam a atenção para a questão do indígena espoliado de sua terra, a busca pela a reafirmação da identidade, e o feminino como força sagrada. Dessa forma, é possível dizer que, nos poemas de Eliane Potiguara, autora e eu lírico se misturam, de modo a não ser possível determinar as fronteiras de cada um, visto que se percebe a sua força engajadora em seus versos. Atualmente, sua obra tem se direcionado também para textos de literatura infantojuvenil, a exemplo dos livros $O$ pássaro encantado (2014) e A cura da terra (2015), abrangendo a temática indígena de forma lúdica e reflexiva.

Assim como Eliane Potiguara, Graça Graúna é descendente do povo potiguara e vive no meio urbano. Seu verdadeiro nome é Maria das Graças Ferreira, mas usa o nome artístico Graúna em duas referências indígenas: primeiramente ao pássaro graúna, derivado do tupi "guira-una" = ave preta, famosa pelo canto e comum na região nordeste, onde se encontra a etnia potiguara, como também ao romance Iracema, em que a personagem indígena é descrita como tendo "cabelos mais negros que a asa da graúna" (ALENCAR, 1991, p. 05). Esse aspecto demonstra a busca pela sua autoafirmação indígena. Além de escritora, Graça Graúna é crítica literária e professora universitária de Literaturas de Língua Portuguesa e Cultura Brasileira, na Universidade de Pernambuco (UPE), onde também coordena o Grupo de Estudos Comparados: Literatura, Memória e Interdisciplinaridade (GRUPEC-UPE). Ela escreveu a primeira obra crítica sobre a literatura indígena no Brasil, intitulada Contrapontos da literatura indígena contemporânea no Brasil (2013).

\footnotetext{
${ }^{2}$ Site oficial de Eliane Potiguara: $<$ http://www.elianepotiguara.org.br/>.
} 
Com relação à Graça Graúna enquanto escritora literária, seu estilo é diversificado, abrangendo desde poemas que apresentam uma estreita relação com memórias do território indígena, como também haicais de cunho filosófico e introspectivo. Além da questão indígena, Graça Graúna também escreve gêneros e textos literários diversos, retomando, por exemplo, cantigas trovadorescas da literatura clássica, além de poemas de versos livres e assimétricos pós-modernos. Segundo entrevista dada a Lima (2015), Graça Graúna publicou também poemas em espanhol e em inglês, o que evidencia a busca por um diálogo interétnico com outras comunidades ameríndias, configurando uma consciência de alteridade social e histórica. Sua formação universitária e sua atuação como crítica literária contribuem para a diversidade na sua escrita, o que justifica também a presença constante da metalinguagem e da intertextualidade em sua obra, além de maior preocupação estilística. Na poesia indigenista de Graça Graúna, há o desejo de reapropriação dos lugares da aldeia, tanto real quanto simbolicamente, e a memória é o elemento evocador, por meio do legado ancestral:

No cerne do pensamento da autora está a ideia de que escrita e deslocamento são inseparáveis na produção literária indígena, tanto pela conexão simbólica e ontológica que esta estabelece com as origens, buscando preencher as lacunas da memória, quanto pelas interações permanentes que é levada a operar com outras culturas e que configuram seu caráter híbrido (OLIVIERI-GODET, 2017, p. 105).

Destaca-se, portanto, uma forma de habitação psíquica na aldeia por meio da poesia, uma vez que a autora não vivenciou o aldeamento, o que coaduna com a obra de Eliane Potiguara nesse sentido, pois conforme explana Olivieri-Godet (2017, p. 105): "Elas reconfiguram, por via da criação literária, sua relação com um meio que não conheceram diretamente". Além disso, como em outras produções de autorias ameríndias contemporâneas, há a poética da alteridade, na busca de evidenciar o indígena na coletividade, nas ânsias em comum.

Considerando esses aspectos, foram selecionados os poemas $A$ denúncia, presente no livro Metade máscara, metade cara, de Eliane Potiguara (2018), e Retratos, da coletânea de poemas Tear da palavra, de Graça Graúna (2007). Esses textos foram escolhidos por trazerem a voz da mulher indígena em protagonismo. A partir das análises de cada um, pretende-se destacar suas aproximações. A seguir, o poema A denúncia:

\author{
Ó mulher, vem cá \\ que fizeram do teu falar? \\ Ó mulher conta aí... \\ Conta aí da tua trouxa \\ Fala das barras sujas \\ dos teus calos na mão \\ O que te faz viver, mulher? \\ Bota aí teu armamento. \\ Diz aí o que te faz calar... \\ Ah! Mulher enganada \\ Quem diria que tu sabias falar! \\ (POTIGUARA, 2018, p. 80).
}

Esse poema apresenta tanto a iniciativa de chamar as mulheres indígenas a se manifestarem, como também de denunciar as mazelas sofridas, como já introduz o título. Com relação ao estilo, nota-se, estruturalmente, versos livres, sem presença de rimas. A linguagem é essencialmente simples, coloquial, direcionada a uma compreensão fácil e acessível, o que 


\section{$=$ TRAMA $=$}

torna a busca de se fazer ouvida mais premente. Ademais, o estilo literário é comparável a clamores, declamações que procuram chamar a atenção do seu interlocutor, o que evidencia uma voz-práxis, a qual pode ser definida como "o lugar e o caminho por excelência para a autoafirmação, autoexpressão, resistência e luta das minorias político-culturais por si mesmas" (DANNER, DORRICO, DANNER, 2018, p. 46). Assim, o eu lírico demonstra uma forte carga expressiva, de maneira que o limite entre ficcionalidade e realidade fica tênue.

O poema procura trazer à tona os obstáculos encontrados pelas mulheres indígenas para terem voz e serem reconhecidas. A primeira estrofe do poema possui o vocativo com função exortadora e o questionamento da própria voz como elementos centrais para essa situação. O eu lírico quer ouvir da própria mulher indígena o que tem acontecido com ela, sem a voz de terceiros. Para isso, chama-a diretamente: "Ó mulher, vem cá". O verso que diz "que fizeram do teu falar?" evidencia o silenciamento imposto, sofrido por essa parte da população brasileira. Essa questão pode ser corroborada por Spivak, quando a autora afirma que "o subalterno como um sujeito feminino não pode ser ouvido ou lido" (SPIVAK, 2010, p. 124). Para tanto, é preciso fazer-se ouvir, e é nesse aspecto que Potiguara finaliza com a segunda estrofe do poema: "Conta aí da tua trouxa/ Fala das barras sujas/ dos teus calos na mão". Esses versos também demonstram que essas mulheres foram despojadas de suas terras, de sua aldeia, "com a trouxa", de modo que são obrigadas a ir à cidade, onde tentam sobreviver como podem, trabalhando até que tenham calos nas mãos. Apesar das circunstâncias, o eu lírico estimula essas mulheres a agirem, a não ficarem na passividade: "Bota aí teu armamento". Esse armamento pode ser falar, não se reprimir: "Diz aí o que te faz calar...", sendo uma forma de denunciar todas degradações sofridas.

Percebe-se a força militante do eu lírico em chamar as mulheres a se manifestarem, o que se justifica pela presença constante de verbos no imperativo juntamente com dêiticos, tais como Conta aí, Fala, Bota aí, Diz aí. Essas formas verbais configuram-se como meio de exortação à mulher indígena, para que se junte às outras, unindo-se, não mais se calando. Além disso, mostra-se como um modo de externar a voz indígena, a fim de se tornar audível para a sociedade em geral: "Ah! Mulher enganada/ Quem diria que tu sabias falar!". Esse verso também aponta para a força que a mulher tem para se fazer ouvida, uma vez que é "enganada" pela sociedade, a qual tenta ocultar essa força, fazendo-a sofrer um apagamento duplo devido ao gênero e à etnia: "Se, no contexto da produção colonial, o sujeito subalterno não tem história e não pode falar, o sujeito subalterno feminino está mais ainda profundamente na obscuridade" (SPIVAK, 2010, p. 67).

No poema Retratos, assim como em A denúncia, está presente todo o anseio de se fazer ouvido/a, além da busca pela união entre as mulheres. O nome do título parece aludir a imagens a serem apresentadas de mulheres em posição subalterna, devido às profissões citadas. Formado por duas estrofes, como percebe-se a seguir, há um eu lírico em $1^{\text {a }}$ pessoa do singular que se propõe a falar com o seu interlocutor no mesmo nível de igualdade, tanto que se refere a ele como "minhas irmãs":

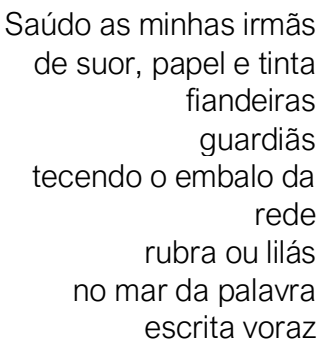




\title{
$=$ TRAMA $=$
}

\author{
Saúdo as minhas irmãs \\ fiandeiras \\ tecelãs \\ cantando a uma só voz \\ o que nós sonhamos \\ o que nós plantamos \\ no tempo em que a \\ nossa voz \\ era só silêncio \\ (GRAÚNA, 2007, p. 24).
}

As irmãs às quais o eu lírico se refere não se restringem apenas às mulheres indígenas. Observa-se que são chamadas todas as mulheres subjugadas, "de suor, papel e tinta", "fiandeiras e tecelãs", ou seja, mulheres trabalhadoras, que são submetidas a uma instância de poder, e, nessa questão, há a busca pela igualdade entre todas. Essas mulheres são incentivadas a agir em conjunto, em comunidade, e o ato da escrita parece ser o instrumento de luta: os versos "tecendo o embalo da rede" e "no mar da palavra/ escrita voraz" podem significar uma comparação, em que assim como uma rede precisa de vários fios entremeados para se formar uma unidade, assim também a escrita necessita dessas mulheres "fiandeiras", de suas palavras em consonância para formar uma história que revele a luta comum de todas elas. No livro Tear da palavra, do qual foi escolhido esse poema, nota-se, já pelo título, a presença metapoética, sendo o poeta comparado a um artesão que tece por meio das palavras. Esse título também pode ser compreendido como o uso da palavra como elemento criador, ou seja, de usar a palavra para se fazer algo, o que confere um traço empoderador para o escritor.

Isso posto, constata-se a presença de metalinguagem em Retratos quando a "escrita voraz" é comparada à tecelagem da rede, não importando a cor, "rubra ou lilás", ou seja, mulheres de todas as cores, raças, unidas na luta em comum. Pode-se remeter que o ato da escrita é voraz, ou seja, não passivo, de forma a incitar as mulheres a se unirem, "cantando a uma só voz/ o que nós sonhamos", para que assim não estejam mais "no tempo em que a nossa voz/ era só silêncio". Essa circunstância evidencia um aspecto obscuro da sociedade patriarcal e capitalista a qual vivemos: "Não há nenhum espaço a partir do qual o sujeito subalterno sexuado possa falar" (SPIVAK, 2010, p. 121). Percebe-se, assim como no poema A denúncia, citado anteriormente, como a emersão da voz é essencial para o empoderamento desse sujeito feminino subjugado.

A partir da análise de Retratos há, portanto, o objetivo de que todas essas mulheres se reúnam, para que, na diversidade de suas posições, consigam se fazer uníssonas e presentes na sociedade. Esse aspecto também está presente no poema $A$ denúncia, uma vez que são chamadas todas as mulheres que estão na última hierarquia, de "calos nas mãos", a terem a força na coletividade expressiva, por meio do verso "Bota aí teu armamento", como também na manifestação da voz: "Diz aí o que te faz calar...".

O principal diferencial entre o poema A denúncia e Retratos está na forma como cada um se propõe a representar a voz das mulheres indígenas. Enquanto $A$ denúncia fala abertamente sobre uma luta engajada, de ação por meio da oralidade, da "denúncia", no poema de Graúna, a força política é mais velada, em que a escrita "voraz", ou seja, sem cessar, é o principal instrumento de luta. Na verdade, o traço de coletividade presente nesses dois poemas de autoria indígena demonstra como a voz-práxis, juntamente à escrita, são instrumentos importantes e interdependentes de uma luta de todas as mulheres indígenas.

Outro ponto a ser considerado em relação ao diferencial desses dois poemas está na forma poética como Eliane Potiguara e Graça Graúna tratam a questão indígena. À medida que Graúna apresenta uma escrita mais impessoal, simbólica, filosófica e lírica, em que o 


\section{$=$ TRAMA $=$}

engajamento político se manifesta nas entrelinhas, exigindo uma leitura mais aprofundada do leitor, Potiguara demonstra a voz-práxis de forma mais ostensiva e aclamatória, e por meio de uma linguagem mais popular. Na verdade, a posição dessas autoras como sujeitos na sociedade se reflete muito em suas obras, uma vez que Eliane Potiguara é ativista de grupos militantes de causas indígenas e Graça Graúna, professora universitária.

Por fim, os poemas supracitados revelam a voz da mulher indígena que quer se fazer ouvida e "lida" diante do recorrente silenciamento, de forma a buscar igualdade, tanto na questão de gênero quanto no direito de possuir sua própria etnia e cultura.

\section{CONSIDERAÇÕES FINAIS}

A literatura de autoria indígena ainda é uma área nova, que, apesar de pouco pesquisada e explorada, tem se mostrado como uma oportunidade de conhecimento de uma parte da história do Brasil desconhecida ainda por muitos, em razão da hegemonia dos discursos de poder na propagação de informações. Graça Graúna e Eliane Potiguara são escritoras engajadas na questão da representatividade indígena, que buscam a afirmação de si e de seus povos, ao mesmo tempo que produzem textos carregados de lirismo e expressividade, o que confirma o aspecto literário. Os poemas analisados dessas duas autoras elegem a voz feminina indígena como enfoque. Enquanto Potiguara evidencia uma posição mais militante por meio de atos públicos e poemas exortadores, Graça Graúna demonstra seu engajamento nas entrelinhas, na reflexão mais metafórica dos seus poemas. De forma geral, há a preocupação por parte dessas autoras que a voz feminina indígena seja externada pela própria mulher, sem a mediação de terceiros, e que essa voz esteja ativa na sociedade.

A partir da leitura dos poemas citados, pode-se dizer que a mulher indígena deve ser autônoma e ter os mesmos direitos que qualquer ser humano. Ela deve se unir com outras mulheres em situação subalterna nessa luta para que suas vozes não sejam mais silenciadas.

\section{REFERÊNCIAS}

ALENCAR, José de. Iracema. 24. ed. São Paulo: Ática, 1991.

ARAÚJO, Ana Claudia. Mulheres retomam papéis protagonistas na cultura indígena. Catarinas, 2016.

Disponível em: <http://catarinas.info/mulheres-retomam-papeis-protagonistas-na-cultura-indigena/\#>. Acesso em: 14 jul. 2018.

BOSI, Alfredo. Literatura e resistência. São Paulo: Companhia das Letras, 2002.

MUNDURUKU, Daniel. Daniel Munduruku. Disponível em: <http://danielmunduruku.blogspot.com/p/danielmunduruku.html>. Acesso em. 10 ago. 2019.

DANNER, Leno Francisco; DORRICO, Julie; DANNER, Fernando. A voz-práxis das minorias entre literatura e política: algumas notas desde a recente produção da literatura indígena brasileira. ANTARES. Caxias do Sul, v. 10, n. 19, p. 45-69, jan/abr 2018. Disponível em: <

http://www.ucs.br/etc/revistas/index.php/antares/article/view/5968/3332>. Acesso em: 28 maio 2018.

ESTÉS, Clarissa Pinkola. Mulheres que correm com os lobos: mitos e histórias do arquétipo da mulher selvagem. Tradução de Waldéa Barcellos. 12. ed. Rio de Janeiro: Rocco, 1999.

FIGUEIREDO, Eurídice. Políticas e poéticas da memória: gênero e etnicidade. In: espelho: autobiografia, ficção, autoficção. Rio de Janeiro: EdUERJ, 2013. p. 149-167.

\section{Mulheres ao}

GRAUNA, Graça. Canto Mestizo. Rio de Janeiro: Ed. Blocos, 1999.

Contrapontos da literatura indígena contemporânea no Brasil. Belo Horizonte: Mazza Edições, 2013. Entrevista com Graça Graúna, escritora indígena e professora da Universidade de Pernambuco: por Tarsila de Andrade Ribeiro Lima. Palimpsesto, Rio de Janeiro, n. 20, jan.-jun. 2015, p. 136-149. Disponível em: <http://www.pgletras.uerj.br/palimpsesto/num20/entrevista/palimpsesto20entrevista01.pdf>. Acesso em: 18 set. 2018 . ISSN: $1809-3507$.

. Tear da palavra. Belo Horizonte: S.n., 2007.

POTIGUARA, Eliane. A cura da terra. São Paulo: Editora do Brasil, 2015.

Histórico. Disponível em:< http://www.elianepotiguara.org.br/>. Acesso em 18 set. 2018.

Metade cara, metade máscara. 2. ed. Lorena: DM Projetos Especiais, 2018.

O pássaro encantado. São Paulo: Jujuba Editora, 2014.

OLIVIERI-GODET, Rita. Graça graúna: A poesia como estratégia de sobrevivência. Interfaces Brasil/Canadá. Florianópolis/Pelotas/São Paulo, v. 17, n. 3, 2017, p. 101-117. 
SANTIAGO, Silviano. O entre-lugar do discurso latino americano. In: Uma literatura nos trópicos. 2. ed. Rio de Janeiro: Rocco, 2000. p. 9-26.

SPIVAK, Gayatri Chakravorty. Pode o subalterno falar? Tradução de Sandra Regina Goulart Almeida. Belo Horizonte: Editora UFMG, 2010.

Enviado em 10-05-19

Aceito em 20-08-19 